\title{
Influence of temperature on the growth and survivability of sichel larvae Pelecus cultratus reared under controlled conditions
}

\author{
Roman Kujawa • Grażyna Furgała-Selezniow • \\ Andrzej Mamcarz • Mariusz Lach • \\ Dariusz Kucharczyk
}

Received: 17 February 2014/Revised: 29 May 2014/ Accepted: 30 May 2014/Published online: 6 July 2014

(C) The Author(s) 2014. This article is published with open access at Springerlink.com

\begin{abstract}
This study analyzed the influence of temperature on the rearing of sichel Pelecus cultratus larvae under controlled conditions. Five constant temperature regimes were tested: $14^{\circ} \mathrm{C}, 18{ }^{\circ} \mathrm{C}, 22^{\circ} \mathrm{C}, 26{ }^{\circ} \mathrm{C}$ and $30^{\circ} \mathrm{C}$. The larvae were reared for 30 days in aquaria with $50 \mathrm{dm}^{3}$ working capacities. The larvae density was 40 individuals/ $\mathrm{dm}^{3}$ and the fish larvae were fed live artemia nauplii. The assessment of the effect of thermal conditions during the rearing period on fish was based on the final size of fish, increment in the total length, relative growth ratio, survivability and condition (the Fulton index). At the end of the 30-day rearing period, it was determined that the largest larvae had been obtained in the $30{ }^{\circ} \mathrm{C}$ water (average weight $374.2 \mathrm{mg}$ with average length $43.1 \mathrm{~mm}$ ). The smallest larvae grew in the coldest water $\left(14{ }^{\circ} \mathrm{C}\right)$, where their average weight was $32.2 \mathrm{mg}$ with an average length of $19.4 \mathrm{~mm}$. No negative effect of temperature was observed on the survivability rate of reared larvae, which oscillated around $91 \pm 5 \%$. Sichel larvae are characterized by high tolerance and high survivability when reared in high-temperature water.
\end{abstract}

Keywords sichel Pelecus cultratus - temperature · growth $\cdot$ survival

R. Kujawa · G. Furgała-Selezniow · A. Mamcarz · M. Lach ·

D. Kucharczyk ( $\square)$

Department of Lake and River Fisheries, Faculty on

Environmental Sciences, University of Warmia and Mazury,

Olsztyn, Poland

e-mail: darekk@uwm.edu.pl

\section{Introduction}

Sichel Pelecus cultratus is a rheophilic cyprinid fish and is the only representative of the genus Pelecus dwelling in the inland waters of Poland (Brylińska 2000). Unlike other cyprinids, it has very long pectoral fins and its body conformation resembles flying fish living in tropical waters. Sichel live in seas and less-saline waters of sea lagoons where the salinity ranges from 0.3 to $5.0 \%$ (in Poland: the Vistula lagoon, the Bay of Szczecin and the Bay of Kamień), as well as in freshwater rivers and artificial dammed reservoirs. The total area where this fish occurs has drastically decreased in recent years (Witkowski 1996; Witkowski and Heese 1996; Witkowski et al. 1999). In the Polish Red Book of Animals, sichel features among other threatened species (code: NT) (Głowaciński 2001). On the Red List of lampreys and fish drawn up for Poland (as of 2009), sichel is listed as a critically threatened species (code: CR) (Witkowski et al. 2009). The quite stable population of this fish can be found only in the Vistula Lagoon, but even there the number of individuals fluctuates greatly (Terlecki 2000). In other water bodies, sichel is perceived as a curiosity and is therefore strictly protected.

Implementation of natural protection (allowable size of caught fish and closed fishing seasons) or conservation methods (protection of natural spawning areas, construction of artificial grounds for spawning) are effective only in water bodies which are slightly transformed and unpolluted. Wherever the natural conditions have been grossly changed, it is necessary to stock waters with fish larvae, a treatment which, while being a much more effective form of the protection of fish species, calls for the development of biotechniques for rearing stocks of larvae under optimal thermal conditions. The literature contains few papers dedicated to the reproduction of sichel or the rearing of its 
larvae under controlled conditions (Kujawa et al. 2013). Most articles deal with the morphometry and nutrition of sichel living in the Vistula Lagoon (Terlecki 1980; Terlecki 1987a, b; Stolarski 1995; Krzykawski and Więcaszek $1997 \mathrm{a}, \mathrm{b})$. This has stimulated a series of studies conducted to design a reproduction technology for rearing sichel larvae under controlled conditions. The elaboration and optimization of such technologies may contribute to the revival of disappearing populations of this unique fish in both Polish and European waters.

Fish are ectotherms and the water temperature produces a profound influence on their reproduction and growth. Both embryonic development and larval growth depend on the ambient water temperature. Changes in the water temperature within a species-specific range may prolong or shorten the duration of development. However, temperatures in excess of this range raise the incidence of defects, which may preclude the proper functioning of an organism or even lead to the death of embryos. Thus, the thermal conditions during fish reproduction as well as fluctuations of temperatures during the embryonic and larval development and growth are the main limiting factors for the presence of any fish species in a given area. Having gained knowledge of the temperatures required by a fish species, we are able to work out successful methods for its reproduction and for the rearing of larvae under controlled conditions (Kucharczyk et al. 1998; Targońska et al. 2014).

The purpose of this study has been to determine the optimal temperature of water for the rearing of sichel larvae under controlled conditions, which is essential for effective, mass-scale production of sichel fish stocking material.

\section{Material and methods}

Material. The research material consisted of sichel larvae obtained from reproduction conducted under controlled conditions. Sichel spawners caught in the Vistula Lagoon (Kujawa et al. 2011) were transported to a fish hatchery at the University of Warmia and Mazury in Olsztyn and placed in fish tanks, each with a capacity of $1000 \mathrm{dm}^{3}$ of water and equipped with water temperature and flow regulators (Kujawa et al. 1999). Sexual germ cells were obtained from spawners (similar in age and size: three females and five males), after having first submitted them to hormonal stimulation (Kujawa et al. 2013). The spawners obtained injection from Ovopel (Horvath et al. 1997) in single injection (dose 1 pellet per $\mathrm{kg}$ ). The oocytes before spawning were not checked because Sichel is multibatch spawners (Targońska et al. 2012). The water temperature during the incubation of spawn was maintained at $19.0 \pm 0.5^{\circ} \mathrm{C}$. The eggs were incubated for five days.
Once the larvae were hatched, they were transferred to shallow rearing tanks which were filled with water at the same temperature. The larvae were kept there for three days, during which they resorbed the contents of the yolk sac. Sichel larvae with partly air-filled swim bladders which had already started swimming in search of food were taken for the experiment.

Methods. The experiment was conducted in five independent, closed, re-circulatory systems (Kujawa et al. 2000). In each system, water from aquaria with larvae was flowing, forced by gravity, through mechanical filters and a biological bed into a lower retention tank, from where it was pumped back to the upper tank. The upper tank contained elements which cooled or warmed the circulating water. Water was forced by gravity to flow from the upper tank to individual aquaria, in which sichel larvae were kept. Water to the tanks with larvae was supplied through rain gun sprinklers. The moment the sichel larvae began to actively swim [three days after hatching (DPH), eight days after fertilization (DPF)], they were placed in aquaria with a working capacity of $50 \mathrm{dm}^{3}$ (three tanks for each temperature variant). The larvae density was 40 individuals/ $\mathrm{dm}^{3}$.

Larvae were reared in fresh water from the water pipework. In order to ensure proper water oxygenation, both the aquaria and the upper tank were fitted with oxygenation systems. The larvae were reared in water at $14{ }^{\circ} \mathrm{C}$, $18{ }^{\circ} \mathrm{C}, 22{ }^{\circ} \mathrm{C}, 26{ }^{\circ} \mathrm{C}$ and $30^{\circ} \mathrm{C}$. Thermal regulators maintained the water temperature at a set level with $0.2{ }^{\circ} \mathrm{C}$ accuracy. The choice of the above temperatures was not incidental. Like vimba (Vimba vimba), chub (Leuciscus cephalus) or barbel (Barbus barbus), sichel begins to reproduce at the turn of May and June, when the water temperature is usually $14-22{ }^{\circ} \mathrm{C}$. In turn, the rearing of rheophilic cyprinid fish larvae under controlled conditions is recommended to take place in water within $25-30{ }^{\circ} \mathrm{C}$ (Kujawa et al. 1997, 1998a, b; Kupren et al. 2011).

Having placed the larvae in aquaria, the circulating water was warmed or cooled $\left(1{ }^{\circ} \mathrm{C} / \mathrm{h}\right)$ until the required temperature was achieved. The experiment was commenced when the desired water temperatures were reached. The photoperiod was set at 12 hours of day and 12 hours of night. The first food was given to larvae 12 hours after they were placed in the rearing tanks. Fish were fed ad libitum four times a day. They received natural food, such as live nauplii of brine shrimp (Artemia sp.) (INVE Aquaculture, Belgium), prepared according to the protocol described by Sorgeloos et al. (1977). Every morning, prior to the first feeding, dead individuals were removed, carefully counted and then used for determination of mortality rate. In addition, uneaten food remains and any contaminants were removed in order to maintain adequate sanitary conditions (Nowosad et al. 2013). The experiment was carried out for 
30 days. The oxygen content was within 7.1-7.8 $\mathrm{mg} \mathrm{O}_{2} /$ $\mathrm{dm}^{3}$; the water $\mathrm{pH}$ varied from 7.2 to 7.4 . No ammonia was detected in the water during the experiment.

The sampling and analysis of larvae. While rearing sichel larvae, the animals were measured and weighed every 4-5 days. The first measurements were taken before the larvae were placed in individual aquaria. The subsequent measurements were performed on 30 individuals from each of the tanks. Before being measured and weighed, the captured larvae were briefly anesthetized in a 2-phenoxyethanol solution according to the method described by Weyl et al. (1996). The concentration of the solution $\left(0.3-0.4 \mathrm{~cm}^{3} / \mathrm{dm}^{3}\right)$ was determined based on the results of the authors' earlier experiments. Anesthetized larvae were measured (total length), using electronic calipers which ensured up to $0.1 \mathrm{~mm}$ accuracy and weighed on analytical scales with $0.1 \mathrm{mg}$ accuracy. Larvae were weighed (after gently draining off on filter paper) in three replications, and the mean wet weight of a single specimen was then calculated (Palinska-Zarska et al. 2014a, b). Next, the larvae were placed in a container with welloxygenated water for saturation. Having resumed active swimming, they were returned to the aquaria from which they had been captured.

The measurements were used to calculate the relative body growth rate (SGR), the index of increases in the total length per time unit (ITL), physical condition, survivability and larvae biomass. The relative specific body growth rate (SGR) and relative biomass growth rate (SBR) from the onset of feeding until the experiment was terminated were computed from the formulas (Brown 1957):

$S G R=100 \frac{\ln \mathrm{W} 2-\ln \mathrm{W} 1}{\Delta \mathrm{t}}$

and

$S B R=100 \frac{\ln (\mathrm{n} 2 \cdot \mathrm{W} 2)-\ln (\mathrm{n} 1 \cdot \mathrm{W} 1)}{\Delta \mathrm{t}}$

where: $\mathrm{W}_{1}-$ mean initial weight of a reared individual (mg),

$\mathrm{W}_{2}$ - mean final weight of a reared individual (mg),

$\mathrm{N}_{1}$ - number of individuals (indiv.) at the onset of rearing,

$\mathrm{N}_{2}$ - number of individuals (indiv.) at the end of rearing,

$\Delta \mathrm{t}-$ duration of the rearing period (days).

Next, based on the above, the relative rate of body gains (RGR) and relative rate of the biomass increase (RBR) from the onset of feeding to the termination of the experiment were computed from the following formulas (Myszkowski, 1997):

$\mathrm{RGR}=100\left(\mathrm{e}^{\frac{\mathrm{SGR}}{100}}-1\right)$ and

$\mathrm{RBR}=100\left(\mathrm{e}^{\frac{\mathrm{SBR}}{100}}-1\right)$

The rates of increments (the SGR and RGR) for the body length were calculated analogously.

The increase in the total length (the ITL) per time unit [mm/d] was derived from the formula (Peňáz et al., 1989):

$I T L=\frac{\mathrm{TL}\left(\mathrm{n}_{2}\right)-\mathrm{TL}\left(\mathrm{n}_{1}\right)}{\Delta \mathrm{t}}$

where:

TL - mean length of an individual (total length)

$\mathrm{n}_{1}-$ start of the period,

$\mathrm{n}_{2}-$ end of the period,

$\Delta \mathrm{t}-$ duration of the rearing (days-d)

The index of length increase and body gain versus the ${ }^{\circ} \mathrm{D}$ temperature at which larvae were reared was:

$D T L=\frac{\mathrm{TL}\left(\mathrm{n}_{2}\right)-\mathrm{TL}\left(\mathrm{n}_{1}\right)}{\sum_{n 2-n 1}{ }^{\circ} D}$

where:

$\mathrm{TL}-$ mean length of an individual (total length)

$\mathrm{n}_{1}$ - onset of the rearing period,

$\mathrm{n}_{2}$ - termination of the rearing period,

$\Delta \mathrm{t}$ - number of degree-days $\left({ }^{\circ} \mathrm{D}\right)$,

Analogously, the body gain per ${ }^{\circ} \mathrm{D}$ was calculated.

The physical condition of larvae was computed from Fulton's equation (Nielsen and Johnson 1983)

$\mathrm{K}=100 \mathrm{~W} / \mathrm{L}^{3}$

where:

$\mathrm{W}$ - mean weight of an individual (mg),

$\mathrm{L}-\mathrm{TL}(\mathrm{mm})$,

The biomass of fish in each tank was determined by multiplying the mean individual weight and the number of live individuals. The obtained value was divided by the capacity of the tanks. The biomass computed as above was expressed in $\mathrm{g} / \mathrm{dm}^{3}$. The day-to-day recorded number of dead fish served to draw up accumulated mortality curves for each rearing variant. Statistical differences in the mortality of larvae between particular groups were analyzed with a $\chi^{2}$ test (Sokal and Rohlf 1969). The $\chi^{2}$ distribution was applied for verification of the zero hypothesis $\left(H_{0}\right)$ that the mortality in each group was the same. Statistical differences between the groups were demonstrated with Duncan's test (1955) at the level of significance of $\alpha=0.05$. The results were subjected to statistical elaboration using Excel 2010 and Statistica 10.0 for Windows software. 


\section{Results}

The growth of larvae in water with different temperatures is presented in Table 1 . The body gains and body length increases at different water temperatures were highly varied and demonstrated different dynamics of changes. The highest mean individual weight was reached by larvae reared in $30{ }^{\circ} \mathrm{C}$ water, where it equaled $374.2 \mathrm{mg}$ (Table 1). This corresponded to an over eleven-fold increase relative to the growth obtained by larvae kept in $14{ }^{\circ} \mathrm{C}$ water. These were statistically significant differences $(P<0.05)$. The daily average RGR for weight was the highest in the warmest water $\left(30^{\circ} \mathrm{C}, 18.86 \% /\right.$ day $)$. The growth of larvae during the larval rearing period is illustrated in Figs. 1 and 2, which additionally comprise parameters of the comparisons which describe the above relationships. The survivability of reared larvae oscillated around $91 \pm 0.5 \%$ and there were no statistical differences between the survivability rates of larvae from the particular groups. The Fulton's body condition index demonstrated small values, within $0.44-0.47$. No statistical differences were found between the value of the Fulton index and the water temperature. The biomass of larvae obtained in particular tanks was markedly different due to large disproportions in the average body weight attained by the growing larvae exposed to different water temperatures. The highest biomass of larvae was found in the warmest water $\left(30^{\circ} \mathrm{C}\right)$, where it reached $13.3 \mathrm{~g} / \mathrm{dm}^{3}$; the lowest biomass equal $1.2 \mathrm{~g} / \mathrm{dm}^{3}$ was determined in the coldest water $\left(14^{\circ} \mathrm{C}\right)$. The larval biomass in water maintained at
$26{ }^{\circ} \mathrm{C}$ reached $10.2 \mathrm{~g} / \mathrm{dm}^{3}$. It was therefore concluded that the optimal range of water temperatures for rearing sichel larvae was $26-30{ }^{\circ} \mathrm{C}$. While analyzing the body gains and length increases relative to the ${ }^{\circ} \mathrm{D}$ of rearing in a given temperature regime, a certain regularity was observed (Figs. 3, 4). As the time passed, the increases in the length of larvae kept at particular temperatures expressed in ${ }^{\circ} \mathrm{D}$ tended to level off, reaching the value of $0.028-0.039 \mathrm{~mm} /$ ${ }^{\circ} \mathrm{D}$ at the end of the rearing period. In turn, the body gain index relative to ${ }^{\circ} \mathrm{D}$ was highly varied between the groups. For larvae maintained in the warmest water $\left(30^{\circ} \mathrm{C}\right)$, it reached $0.41 \mathrm{mg} /{ }^{\circ} \mathrm{D}$, whereas in the $14{ }^{\circ} \mathrm{C}$ water it equaled $0.08 \mathrm{mg} /{ }^{\circ} \mathrm{D}$.

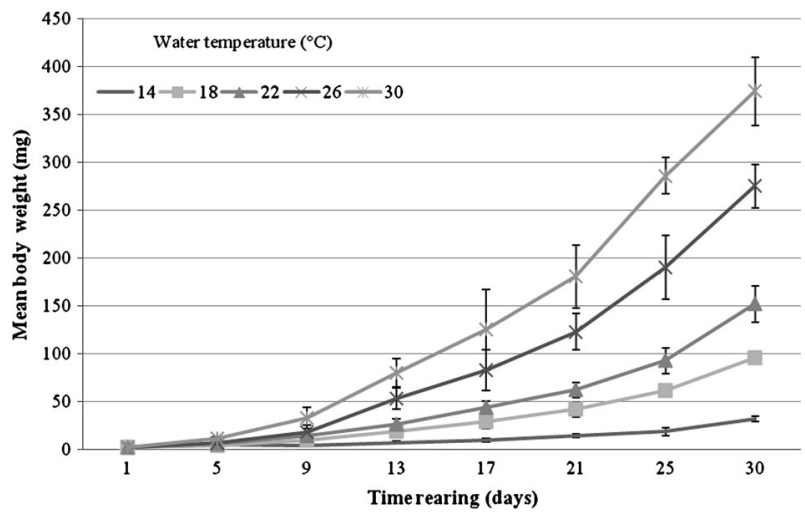

Fig. 1 Growth rate of weight of juvenile sichel reared at different water temperatures

Table 1 The results of rearing sichel larvae (Pelecus cultratus) at different water temperatures

\begin{tabular}{|c|c|c|c|c|c|}
\hline \multirow[t]{2}{*}{ Parameter } & \multicolumn{5}{|c|}{ Water temperature $\left({ }^{\circ} \mathrm{C}\right)$} \\
\hline & 14 & 18 & 22 & 26 & 30 \\
\hline Initial mean body weight (mg) & $2.1 \pm 0.1^{a}$ & $2.1 \pm 0.1^{a}$ & $2.1 \pm 0.1^{a}$ & $2.1 \pm 0.1^{a}$ & $2.1 \pm 0.1^{a}$ \\
\hline Final mean body weight (mg) & $32.2 \pm 3.0^{a}$ & $96.0 \pm 6.4^{b}$ & $152.0 \pm 18.5^{c}$ & $275.5 \pm 22.7^{d}$ & $374.2 \pm 35.9^{e}$ \\
\hline Initial mean body length (mm) & $7.8 \pm 0.2^{a}$ & $7.8 \pm 0.2^{a}$ & $7.8 \pm 0.2^{a}$ & $7.8 \pm 0.2^{a}$ & $7.8 \pm 0.2^{a}$ \\
\hline Final mean body length (mm) & $19.4 \pm 0.4^{a}$ & $27.3 \pm 0.3^{b}$ & $32.3 \pm 0.8^{c}$ & $38.7 \pm 1.4^{d}$ & $43.1 \pm 1.1^{e}$ \\
\hline Initial stock (individual) & 2000 & 2000 & 2000 & 2000 & 2000 \\
\hline Final stock (individual) & $1784 \pm 6.4^{a}$ & $1810 \pm 4.4^{a}$ & $1830 \pm 5.3^{a}$ & $1845 \pm 3.4^{a}$ & $1780 \pm 2.8^{a}$ \\
\hline Survival (\%) & $89.2 \pm 0.6^{a}$ & $90.5 \pm 0.7^{a}$ & $91.5 \pm 0.5^{b}$ & $92.3 \pm 0.4^{b}$ & $89 \pm 0.6^{a}$ \\
\hline Increase in total length $(\mathrm{ITL})(\mathrm{mm} / \mathrm{d})$ & $0.39 \pm 0.01^{a}$ & $0.65 \pm 0.02^{b}$ & $0.82 \pm 0.02^{c}$ & $1.03 \pm 0.03^{d}$ & $1.18 \pm 0.03^{e}$ \\
\hline Relative growth rate (RGR) for weight (\%/d) & $9.53 \pm 0.4^{a}$ & $13.59 \pm 0.3^{b}$ & $15.34 \pm 0.6^{c}$ & $17.65 \pm 0.4^{d}$ & $18.86 \pm 0.5^{e}$ \\
\hline Relative growth rate (RGR) for length $(\% / \mathrm{d})$ & $3.08 \pm 0.1^{a}$ & $4.26 \pm 0.2^{b}$ & $4.85 \pm 0.2^{c}$ & $5.49 \pm 0.3^{d}$ & $5.86 \pm 0.2^{e}$ \\
\hline Relative growth rate (RBR) for biomass (RBR) $(\% / d)$ & $9.11 \pm 0.5^{a}$ & $13.21 \pm 0.4^{b}$ & $15.00 \pm 0.5^{c}$ & $17.34 \pm 0.3^{d}$ & $18.40 \pm 0.4^{e}$ \\
\hline Biomass $\left(\mathrm{g} / \mathrm{dm}^{3}\right)$ & $1.15 \pm 0.2^{a}$ & $3.48 \pm 0.3^{b}$ & $5.56 \pm 0.3^{c}$ & $10.17 \pm 0.5^{d}$ & $13.32 \pm 0.6^{e}$ \\
\hline Fulton $\mathrm{K}$ & $0.44 \pm 0.03^{a}$ & $0.47 \pm 0.02^{b}$ & $0.45 \pm 0.03^{a}$ & $0.47 \pm 0.02^{b}$ & $0.47 \pm 0.02^{b}$ \\
\hline $\mathrm{Dm}\left(\mathrm{mg} /{ }^{\circ} \mathrm{D}\right)$ & $0.072 \pm 0.00$ & $0.174 \pm 0.01$ & $0.227 \pm 0.02$ & $0.351 \pm 0.01$ & $0.413 \pm 0.02$ \\
\hline $\mathrm{Dd}\left(\mathrm{mm} /{ }^{\circ} \mathrm{D}\right)$ & $0.028 \pm 0.00$ & $0.036 \pm 0.00$ & $0.037 \pm 0.00$ & $0.040 \pm 0.00$ & $0.039 \pm 0.00$ \\
\hline
\end{tabular}

Mean value \pm S.D. Results in rows with the same letter index are not statistically significantly different $(P \leq 0.05)$ 
Fig. 2 Growth rate of length of juvenile sichel reared at different water temperatures

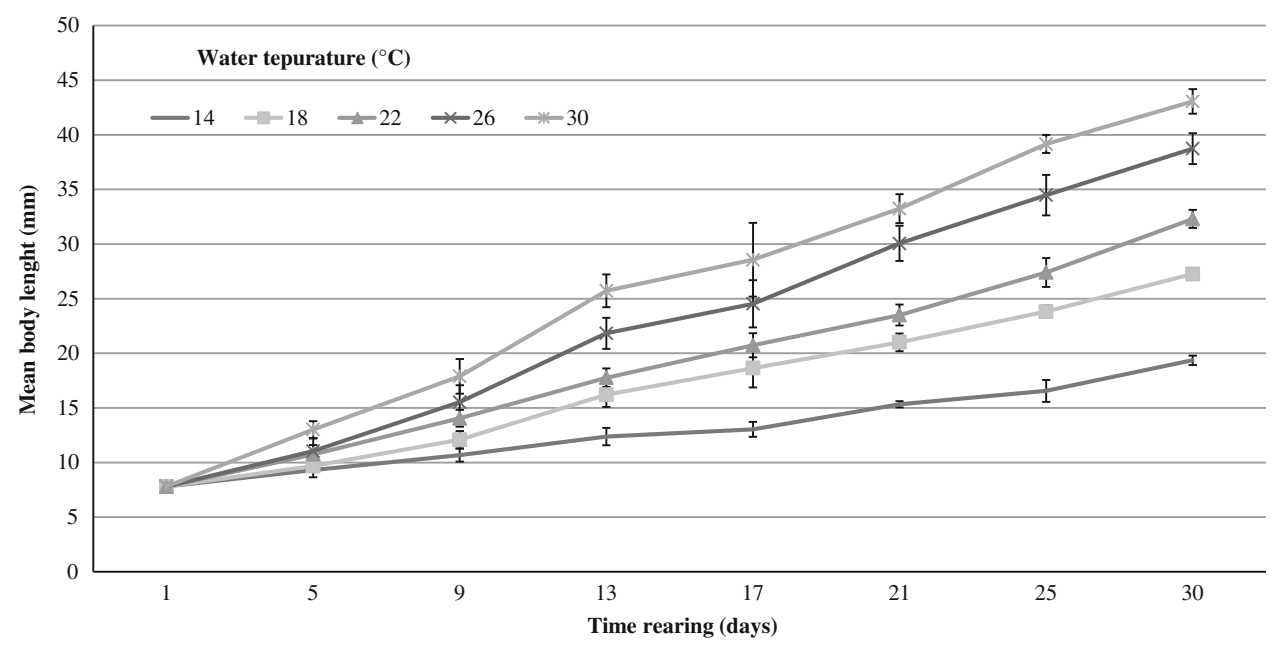

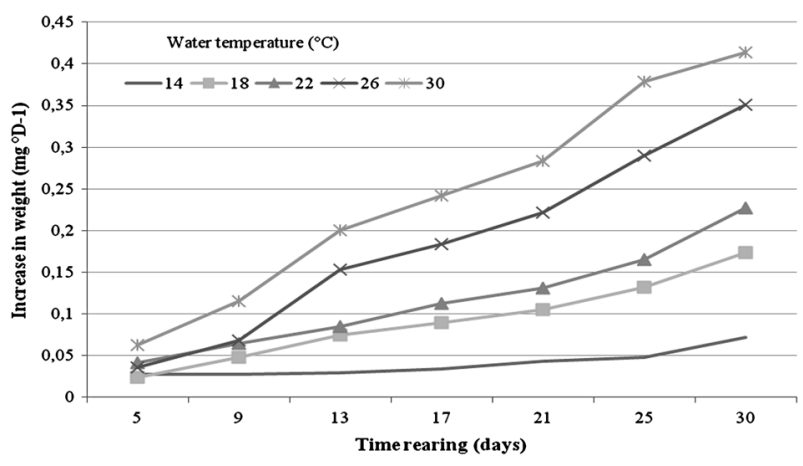

Fig. 3 Growth rate of sichel larvae weight calculated on degree days $\left({ }^{\circ} \mathrm{D}\right)$

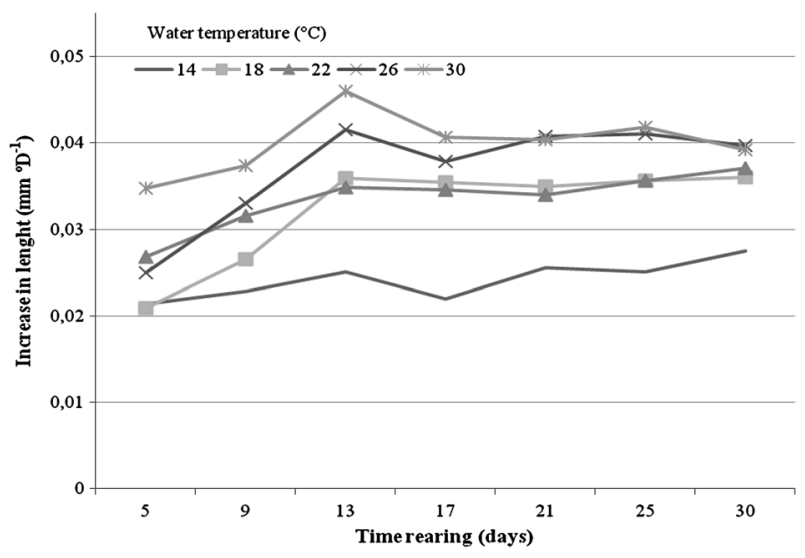

Fig. 4 Growth rate of sichel larvae length calculated on degree days ( $\left.{ }^{\circ} \mathrm{D}\right)$

\section{Discussion}

The early developmental stages of fish are the least tolerant to various environmental factors. It is therefore crucial to recognize their requirements in order to pursue research on fish reproduction and the rearing of juvenile forms. The thermal gradient during the spawning season and the temperature of water in which the embryonic development and larval growth proceed are factors which may limit the occurrence of a given fish species in a specific location. Species inhabiting vast geographical territories are highly adaptable to different aquatic temperatures (Kokurewicz 1971). It is not rare that water temperatures change rapidly, which means that fish can survive such unfavorable conditions only by being tolerant and adaptable to changeable thermal conditions (Wiegand et al. 1988). In a controlled environment, the growth and development of larvae are also affected by a number of factors, including amounts of dissolved oxygen, quality and quantity of food and water temperature (Kucharczyk et al. 1997, 1998; Kujawa et al. 1997, 1998a, b, 2007; Kujawa 2004).

The literature implies that the tolerance of fish to changes and temperature levels increases with age, but at the same time the upper bound of optimum and growthstimulating temperatures moves 'upwards' (Backiel and Horoszewicz 1970; Opuszyński 1983; Laurila et al. 1987). On the other hand, strongly fluctuated temperature during beginning of the embryonic development should implicate on the ploidy level of embryos (Kucharczyk et al. 2014; Nowosad et al. 2014). It is a distinguishing feature of cyprinid fish that the range of temperatures optimal for the rearing of their larvae is much higher than the temperatures of waters recorded in the natural environment (Wolnicki and Appelbaum 1993; Wolnicki and Górny 1993, 1994; Kujawa et al. 1998b). This is why the range of temperatures tolerated by sichel larvae is much higher than the range determined for the incubation of its spawn. On the other hand, Siegel live in a large area in Europe, so it is possible to wide adaptation to water temperatures.

The intensity of metabolic conversion for fish adheres to Krogh's curve (Backiel and Horoszewicz 1970), according to which the metabolic rate of fish kept in $30{ }^{\circ} \mathrm{C}$ water is nearly 2.3 -fold faster than when fish live in $20{ }^{\circ} \mathrm{C}$ water. 
On the other hand, the intensity of the metabolic rate in fish dwelling in colder water such as $14{ }^{\circ} \mathrm{C}$ is almost 0.6 -fold slower than in $20{ }^{\circ} \mathrm{C}$ water. Recapitulating, the rate of metabolic conversion at $30{ }^{\circ} \mathrm{C}$ is nearly fourfold faster than that of larvae kept at $14{ }^{\circ} \mathrm{C}$. As the metabolic rate increases under the influence of warm water temperatures, the oxygen consumption by fish increases. In turn, the solubility of oxygen in water declines at higher water temperatures, which is why water needs to be effectively oxygenated to increase the oxygen concentration and it may sometimes even be necessary to introduce pure oxygen to water.

However, the fish's metabolic rate does not change as quickly as the water temperature. Rather, it reaches a level that is adequate to the prevailing thermal conditions with some delay. The rate at which a fish's metabolism adjusts to the thermal conditions depends on whether the water temperature has risen or fallen. The metabolic rate adapts much more quickly when larvae are transferred to water than to colder water (Backiel and Horoszewicz 1970). This characteristic pattern of adaptability of larvae to new thermal conditions must be borne in mind when stocking water with fish larvae, which should be gradually adapted to water temperatures for an adequately long period before being released to open waters.

There is a certain, small range of temperatures in which - owing to the regulatory abilities of a fish larval organism - the metabolic conversion rate does not change or else these changes are very small despite fluctuations in water temperatures. The amount of ingested and not completely digested food increases within a certain range of water temperatures, first peaking and then decreasing as the temperature continues to rise. While the temperature grows, the time needed for digesting food decreases and therefore the rate of digestion is higher. The adaptation of fish to changeable water temperatures often induces changes in the foraging rate. A higher temperature means faster foraging, while decreased temperature initially does not change the rate of foraging. It is only after a certain time which larvae need to adapt to a new, lower temperature that the metabolic rate changes as well. Optimal temperatures for the growth of larvae are also optimal for the foraging and conversion of food to body gain. Larvae reared at higher temperatures are not only characterized by a larger body size, but they are also distinguished by a much larger size differentiation. At lower temperatures, the growth is much more uniform and there are not such large differences between individuals as in the warmer water (Laurila et al. 1987; Kucharczyk et al. 1998).

When analyzing the results of the sichel larva rearing presented above, a close dependence became apparent between the growth of larvae and water temperature: the warmer the water, the higher the growth of sichel larvae. The data regarding the body gains of sichel larvae kept under different water temperature regimes are similar to the results achieved from studies on rearing other rheophilic cyprinid fish at different water temperatures (Kucharczyk et al. 1997, 1998; Kujawa et al. 1997, 1998a, b, 2007; Kupren et al. 2011). The longer the larval rearing period in warm water, the greater the growth gains, both in terms of the mean biomass of larvae and the total length. In the described rearing experiment, the largest larvae grew in the warmest water $\left(30^{\circ} \mathrm{C}\right)$. However, due to the costs of heating water under controlled conditions, in facilities which are used for rearing fish stock material, sichel larvae can be produced in slightly less warm water, such as $26^{\circ} \mathrm{C}$. Based on the research completed to date, $26{ }^{\circ} \mathrm{C}$ was found to be the best for the growth of juvenile sichel and likewise can be considered optimal for the rearing of its larvae. It is therefore a recommendable thermal regime for the production of fish stock material. As more stocking material can be produced in a relatively short time, the costs of running fish stock material production, purchase and preparation of feeds and costs of heating water are decreased. The temperature of $30^{\circ} \mathrm{C}$, despite stimulating the highest growth of larvae, is not recommended for mass fish rearing due to the costs of heating water and the risk of losing fish due to thermoregulation or water oxygenation system failure. The fact that larvae reared in water at this temperature reached an average weight of $374.2 \mathrm{mg}$ and were distinguished by a high survivability rate prove that larvae of the fish species are highly tolerant to high water temperatures during the rearing period. To a large extent, the volume of reared stocking material is vital for its survival in the natural environment and, consequently, for the size of a future fish spawning school. Thus, when planning to stock water bodies for restitution of fish species, it is recommended to use stocking material composed of larvae of a size that will minimize the predatory pressure it is subjected to.

The research results demonstrate that there is a positive relationship between the water temperature and larval growth. Once it is determined what body gains are achieved by sichel larvae kept in different water temperatures, it will be possible to produce fish stocking material of a desired size in a given time by manipulating the water temperature. The low value of the Fulton index regardless of the water temperature does not mean that the physical condition of the larvae was poor, but is closely related to the shape of the body of sichel fish, which are elongated, not very tall and are laterally strongly flattened.

Acknowledgments This research was financed by the NCN (the Polish National Science Centre) under the research project number NN 304302640.

Open Access This article is distributed under the terms of the Creative Commons Attribution License which permits any use, 
distribution, and reproduction in any medium, provided the original author(s) and the source are credited.

\section{References}

Backiel T, Horoszewicz L (1970) Temperature a fish. Broszura IRŚ 4:1-25

Brown ME (1957) Experimental studies on growth. In: Brown ME (ed) The physiology of fishes. Academic Press, New York, pp 361-400

Brylińska M (2000) Polish inland water fish. PWN, Warszawa

Duncan DB (1955) Multiple range and multiple F-test. Biometrics 11:1-42

Głowaciński Z (2001) The polish red data book of animals. PWRiL, Warszawa

Horvath L, Szabo T, Burke J (1997) Hatchery testing of GnRH analogue-containing pellets on ovulation in four cyprinid species. Polish Arch Hydrobiol 44:221-226

Kokurewicz, B (1971) Thermal conditions of spawning and development of some fish species. Wydaw. IRS Olsztyn Oprac Brosz $\mathrm{Nr} 47: 1-18$

Kucharczyk D, Łuczyński M, Kujawa R, Czerkies P (1997) Effect of temperature on embryonic and larval development of bream (Abramis brama L.). Aquatic Sci 59:214-224

Kucharczyk D, Łuczyński M, Kujawa R, Kamiński R, Ulikowski D, Brzuzan P (1998) Influence of temperature and food on early development of bream (Abramis brama L.). Arch. Hydrobiol 141:243-256

Kucharczyk D, Żarski D, Targońska K, Łuczyński M J, Szczerbowski A, Nowosad J, Kujawa R, Mamcarz A (2014) Induced artificial androgenesis in common tench, Tinca tinca (L.), using common carp and common bream eggs. Ital J Anim Sci 13:196-200

Kujawa R, Mamcarz A, Kucharczyk D, (1997) Effect of temperature on embryonic development of asp (Aspius aspius L.). Pol Arch Hydrobiol 44:139-143

Kujawa R, Kucharczyk D, Mamcarz A, Skrzypczak A (1998a) The rearing methods of ide (Leuciscus idus L.) and dace (Leuciscus leuciscus L.) on artificial diets. Eur Aquacult Soc Spec Publ 26:153-154

Kujawa R, Mamcarz A, Kucharczyk D (1998b) Influence of temperature on asp (Aspius aspius L.) larval development. Czech J Anim Sci 43:396-396

Kujawa R, Kucharczyk D, Mamcarz A (1999) A model system for keeping spawners of wild and domestic fish before artificial spawning. Aquacult Eng 20:85-89

Kujawa R (2004) Biological background for rearing reophylic cyprinid larvae under controlled conditions. Monography Olsztyn $88: 1-88$

Kujawa R, Mamcarz A, Kucharczyk D (2007) Postembryonic developmental stages of asp Aspius aspius (L.) Pol J Natl Sci 22:239-246

Kujawa R, Mamcarz A, Kucharczyk D, Skrzypczak A (2000) An experimental unit for rearing larval freshwater fish. Folia Univ Agri Stetin Piscatoria 26:103-108

Kujawa R, Pol P, Mamcarz A, Furgała-Selezniow G (2011) Preliminary studies on fishing and transport of the sichel (Pelecus cultratus L., 1758) for reproduction under controlled conditions. In: Jankun M, Furgała - Selezniow G, Woźniak M, Wiśniewska A (eds) Fish management in a water environmental. M Fish Will, Olsztyn, pp 201-205

Kujawa R, Kucharczyk D, Mamcarz A, Furgała-Selezniow G, Glińska-Lewczuk K (2013) Possibility of artificial reproduction of sichel Pelecus cultratus (L.) under controlled conditions. Wulfenia J 20:82-91
Kupren K, Żarski D, Krejszeft S, Kucharczyk D, Targońska K (2011) Effect of stocking density on growth, survival and development of asp Aspius aspius (L.), ide Leuciscus idus (L.) and chub Leuciscus cephalus (L.) larvae during initial rearing under laboratory conditions. Ital J Anim Sci 10:178-184

Krzykawski S, Więcaszek B (1997a) Biometric characteristics of sabrefish Pelecus cultratus (L.), saithe Pollachius virens (L.) and sea bass Dicentrarchus labrax (L.) from new localities in Polish waters. Acta Ichthyol Piscator 2:3-15

Krzykawski S, Więcaszek B (1997b) New locality of sabrefish Pelecus cultratus (L.1758) (Pisces: Cyprinidae), a very rare species in northwest Poland. Przegląd Zool 41:79-82

Laurila S, Piironen J, Holopainen IJ (1987) Notes on egg development and larval and juvenile growth of crucian carp (Carassius carassius (L.)). Annal Zool Fennici 24:315-321

Myszkowski L (1997) Pitfalls of using growth rate coefficients. Pol. Arch. Hydrobiol 44:389-396

Nielsen LA, Johnson DL (1983) Fisheries techniques. American Fish Soc Publ, Bathesda, Maryland

Nowosad J, Żarski D, Biłas M, Dryl K, Krejszeff S, Kucharczyk D (2013) Dynamics of ammonia excretion in juvenile common tench, Tinca tinca $(\mathrm{L}$.$) , during intensive rearing under controlled$ conditions. Aquacult Int 21:629-637

Nowosad J, Kucharczyk D, Liszewski T, Targońska K, Kujawa R (2014) Comparison of temperature shock timing to induced artificial mitotic gynogenesis and androgenesis in common tench. Aquacult Int doi 10.1007/s10499-014-9796-0

Opuszyński K (1983) Podstawy Biologii Ryb. PWR i L, Warszawa

Palińska-Zarska K, Zarski D, Krejszeff S, Nowosad J, Bilas M, Trejchel K, Brylewski A, Targońska K, Kucharczyk D (2014a) The effect of age, size and digestive tract development on burbot, Lota lota (L.), larvae weaning effectiveness. Aquacult Nutr 20:281-290

Palińska-Żarska K, Żarski D, Krejszeff S, Nowosad J, Biłas M, Trejchel K, Kucharczyk D (2014b) Dynamics of yolk sac and oil droplet utilization and behavioural aspects of swim bladder inflation in burbot, Lota lota L., larvae during the first days of life, under laboratory conditions. Aquacult Int 22:13-27

Peňáz M, Prokeš M, Kouřil J, Hamáčková J (1989) Influence of water temperature on the early development and growth of the tench, Tinca tinca. Folia Zool 38:275-287

Sokal RR, Rohlf JR (1969) Biometry. The principles and practice of statistics in biological research. H.F. Freeman and Co, San Francisco

Sorgeloos P, Bossuyt E, Lavina E, Baeza-Mesa M, Persoone G (1977) Decapsulation of Artemia cysts: a simple technique for the improvement of the use of brine shrimp in aquaculture. Aquacult $12: 311-315$

Stolarski J (1995) Sichel (Pelecus cultratus L.) from the Vistula Lagoon. Bull Sea Fish Inst 2(135):11-21

Targońska K, Perkowski T, Żarski D, Krejszeff S, Mamcarz A, Kujawa R, Kucharczyk D (2012) Method of evaluation of wild common tench, Tinca tinca (L.), female suitability for artificial reproduction during the spawning season. Ital J Anim Sci 11:164-168

Targońska K, Zarski D, Kupren K, Palińska-Zarska K, Mamcarz A, Kujawa R, Skrzypczak A, Furgała-Selezniow G, Czarkowski TK, Hakuć-Błazowska A, Kucharczyk D (2014) Influence of temperature during four following spawning seasons on the spawning effectiveness of common bream, Abramis brama (L.) under natural and controlled conditions. J Therm Biol 39:17-23

Terlecki J (1980) Meristic and biometric features of Pelecus cultratus (L.) from the Vistula Lagoon. Acta Acad Agr Tech Olst Protect Aqua Pisc 10:193-203 
Terlecki J (1987a) Growth of Pelecus cultratus (L.) from the Vistula Lagoon. Acta Acad Agr Tech Olst Protect Aqua Pisc 15:27-36

Terlecki J (1987b) Individual fecundity of Pelecus cultratus (L.) from the Vistula Lagoon. Acta Acad Agr Tech Olst Protect Aqua Pisc 15:37-47

Terlecki J (2000) Poradniki ochrony siedlisk i gatunków Natura 2000 - podręcznik metodyczny. Gatunki zwierzạt (z wyjątkiem ptaków). Ciosa Ministerstwo Środowiska, Warszawa

Weyl O, Kaiser H, Hecht T (1996) On the efficacy and of action of 2-phenoxyethanol as an anaesthetic for goldfish, Carassius auratus (L.), at different temperatures and concentrations. Aquacult Res 27:757-764

Wiegand MD, Buchanan LG, Loewen JM, Hewitt CM (1988) Effects of rearing temperature on development and survival of embryonic and larval goldfish. Aquacult 71:209-222

Witkowski A (1996) Changes in the fish fauna of Polish rivers: native species and introduced. Zool Poloniae 41:29-40
Witkowski A, Heese T (1996) Protection of rare and endangered fish in Poland, current status and perspectives. Zool Poloniae 41:1-195

Witkowski A, Błachuta J, Kotusz J, Heese T (1999) The red list of freshwater lampreys and fishes in Poland. Chrońmy Przyr Ojcz 55:5-19

Witkowski A, Kotusz J, Przybylski M (2009) Stopień zagrożenia słodkowodnej ichtiofauny Polski. In: Witkowski A (ed) The red list of freshwater lampreys and fishes in Poland -2009. Chrońmy Przyr, Ojcz, pp 33-52

Wolnicki J, Appelbaum S (1993) Optimal growth temperature for koi carp (Cyprinus carpio L.) larvae and juveniles reared under controlled conditions. Pol Arch Hydrobiol 40:223-230

Wolnicki J, Górny W (1993) Thermal optimum growth of juvenile asp Aspius aspius L. and barbel Barbus barbus L. Kom Ryb 2:9-10

Wolnicki J, Górny W (1994) Thermal optimum growth of juvenile nase, Chondrostoma nasus L. Kom Ryb 2:18-19 